\title{
Strategi Meningkatkan Motivasi Belajar Siswa Selama Pandemi Covid - 19 : Literature Review
}

\author{
Eis Imroatul Muawanah ${ }^{\left.1^{*}\right)}$ Abdul Muhid ${ }^{2}$ \\ ${ }^{12}$ Universitas Islam Negeri Sunan Ampel Surabaya \\ *Corresponding author, e-mail: eisimroatulm@gmail.com
}

Received January 12th , 2021; Revised Month February 1st, 2021;

Accepted March 15, 2021; Published Online March 20, 2021

\section{Conflict of Interest} Disclosures:

The authors declare that they have no significant competing financial, professional or personal interests that might have influenced the performance or presentation of the work described in this manuscript.

\begin{abstract}
This study aims examine strategies to increase student motivation during the covid - 19 pandemic. This research is a literature review where the researcher conducts an in-depth study of previous studies. Strategies to increase student motivation during the covid - 19 pandemic were found in various ways, such as persuasive communication, ACRS Techniques, using animated video, Virtual Laboratory, active teacher roles, creative teachers, Class Discussion, Role Play Method, Comic Media, Audio Visual Media, Blended Learning Method, Quantum Learning Strategy, lightening the learning climate learning strategy, Think Pair Share (TPS) learning strategy, Genius Learning, SAVI Learning Strategy, stong wind gust strategy, Inquiry Learning Strategy, cooperative learning model spotlight strategy. What students need to understand is that no matter how great motivator is, if there is no desire from within, the motivation will never be realized.
\end{abstract}

Keywords: Motivation to Learn, Students, Covid - 19

Indonesian Abstract: Penelitian ini bertujuan untuk mengkaji strategi peningkatan motivasi siswa selama pandemi COVID-19. Penelitian ini merupakan studi pustaka dimana peneliti melakukan studi mendalam terhadap penelitian sebelumnya. Strategi untuk meningkatkan motivasi siswa selama pandemi COVID-19 ditemukan dengan berbagai cara, seperti komunikasi persuasif, Teknik ACRS, menggunakan video animasi, Laboratorium Virtual, peran aktif guru, guru kreatif, Diskusi Kelas, Metode Role Play, Media Komik, Audio Media Visual, Metode Pembelajaran Blended, Strategi Pembelajaran Quantum, Strategi Pembelajaran Peringan Iklim, Strategi Pembelajaran Think Pair Share (TPS), Pembelajaran Genius, Strategi Pembelajaran SAVI, Strategi Stong Wind Gust, Strategi Pembelajaran Inkuiri, Strategi Lampu Sorot Model Pembelajaran Kooperatif. Yang perlu dipahami siswa adalah bahwa sekuat apapun motivatornya, jika tidak ada keinginan dari dalam, maka motivasi tersebut tidak akan pernah terwujud.

Kata Kunci: Motivasi Belajar, Siswa, Covid - 19

How to Cite: Eis Imroatul Muawanah, Abdul Muhid. 2021. Strategi Meningkatkan Motivasi Belajar Siswa Selama Pandemi Covid - 19 : Literature Review. JIBK Undiksha, 12 (1): pp.90-98. DOI: http://dx.doi.org/10.23887/xxxx

\section{Pendahuluan}

Semenjak penghujung tahun 2019 dunia dihebohkan dengan adanya virus corona / covid-19. Virus ini menyebar luas hingga ke berbagai belahan dunia termasuk Negara Indonesia. Hingga pada Bulan April pemerintah Indonesia mengumumkan kebijakan lockdown yaitu pembatasan dalam seluruh aktivitas, yang 
melakukan pembatasan dalam aktivitas peribadahan, sekolah, perkantoran, ataupun sarana universal, aktivitas sosial serta budaya, moda transportasi, dan aktivitas yang lain yang berhubungan dengan keamanan wilayah sebagian persyaratan wajib diikuti oleh daerah yang mengikuti peraturan lockdown. Penerapan lockdown dalam konteks pembelajaran berdasarkan Permenkes RI Nomor. 9 Tahun 2020 menyatakan bahwa sekolah diliburkan dan mengubah kegiatan belajar mengajar dipindahkan dirumah dengan menggunakan media internet. Dengan adanya kebijakan tersebut, maka segala bentuk aktivitas menggunakan sistem online dengan menggunakan internet. Terdapatnya kebijakan lockdown tersebut membagikan hambatan dan tantangan baru untuk seluruh lembaga pendidikan. Dalam penerapan peliburan sekolah pada masa pandemi ini mengharuskan terjalinnya kerjasama yang baik di berbagai lapisan masyarakat.

Upaya pemaksimalan tujuan pendidikan yang diinginkan dengan berbagai metode pembelajaran yang digunakan untuk menumbuhkan motivasi belajar siswa. Salah satu caranya yaitu pengajar wajib menguasai teknik mengajar dalam proses belajar mengajar (Syaparuddin et al., 2018). Penelitian oleh Hamzah B Uno (Uno \& Ma'ruf, 2016) menyatakan motivasi merupakan dorongan terhadap diri individu untuk melakukan perilaku yang diinginkannya. Kemudian oleh Menurut Sumadi Suryabrata (Prasojo, 2016) menyatakan bahwa, motivasi adalah keinginan atau dorongan yang ada pada diri seseorang untuk melakukan sesuai tujuan yang akan dicapainya. Menurut Mc Donald (Febnasari et al., 2019) motivasi adalah suatu perubahan energi yang ada pada diri individu yaitu munculnya aksi agar mencapai tujuan yang diinginkan. Motivasi belajar ialah faktor penting adanya aktivitas \& hasil pembelajaran yang berada dalam aspek psikologis siswa, menurut (Safitri, Firharianti \& Sahal, 2017) hasil belajar siswa memiliki sangat banyak faktor yang dapat mempengaruhi. Akan tetapi, yang lebih penting ialah: kecerdasan siswa, tingkah laku, kemampuan, minat dan motivasi siswa.

Terdapatnya pergantian proses pendidikan di tengah pandemic seperti sekarang ini menjadikan sesuatu tantangan tertentu untuk segala lembaga pembelajaran. Menurut (ARIANTI, 2019) mengatakan pada risetnya yang dicoba pada suatu sekolah besar swasta, kalau area belajar cukup berpengaruh terhadap motivasi belajas para siswa. Area belajar wajib diciptakan sepositif bisa jadi setara dengan area sekolah, supaya motivasi belajar siswa bisa berkembang. Apabila area sekolah bermutu, hingga hendak terbentuk motivasi belajar siswa besar, serta hendak bisa tingkatkan hasil belajar siswa (Jamco, 2015). Tidak hanya itu, motivasi belajar intrinsik ataupun ekstrinsik wajib dimiliki oleh siswa sebab berperan penting supaya tujuan pendidikan yang diinginkan bisa tercapai, dan supaya terdapatnya motivasi tersebut bisa membagikan support kepada para siswa sehingga bisa mengenali alur belajarnya (Rahardja et al., 2018). Berdasarkan penjelasan diatas betapa pentingnya motivasi belajar pada kegiatan pembelajaran. Terdapatnya motivasi belajar wajib diusahakan terdapat pada siswa tersebut, serta apabila terdapat rintangan dapat diupayakan untuk diminimalkan. Sehingga hasil belajar yang diinginkan dapat dicapai secara optimal.

Manfaat riset ini yaitu untuk memberikan pandangan dari berbagai macam startegi dalam meningkatkan motivasi belajar para siswa selama pandemic covid - 19. Selanjutnya, dijelaskan pula tentang hambatan hambatan dalam meningkatkan motivasi belajar siswa, kemudian macam - macam motivasi, faktor yang mempengaruhi motivasi belajar siswa, dan yang terakhir yaitu berbagai macam strategi yang dapat dilakukan untuk meningkatkan motivasi belajar siswa pada masa pandemi covid - 19 .

\section{Metode}

Metode dalam proses penulisan artikel ini yaitu literature review. Pencarian literature baik internasional maupun nasional yang dilakukan dengan menggunakan database EBSCO, ScienDirect, Proquest, ISJD, Scoolar, Garuda Ristekbrin, dan lain - lain. Pada tahap awal pencarian artikel jurnal diperoleh lebih dari 10 artikel dari tahun 2001 sampai tahun 2020 dengan menggunakan kata kunci "strategi meningkatkan motivasi belajar siswa" yang diindentifikasi tetapi belum dieksplorasi relevansi dengan berbagai artikel untuk dikompilasi. Dari jumlah diatas hanya sekitar 3 artikel yang dianggap sesuai.

Dalam konteks ini, penulis dalam membahas strategi peningkatan motivasi belajar menggunakan pendekatan psikologi bimbingan dan konseling sebagai ilmu yang mempelajari tentang layanan bagi siswa baik secara psikologis maupun secara fisik dalam konteks sekolah. Tidak hanya aspek psikologis akan tetapi juga diperhatikan berbagai aspek dalam diri maupun dari luar diri siswa tersebut misalnya seperti minat belajar, teman sebaya disekolah, prestasi siswa dan lain sebagainya. 


\section{Hasil dan Pembahasan}

\section{Pengertian Motivasi Belajar}

Motivasi memiliki arti kata motif yaitu dorongan dari dalam diri individu guna melakukan kegiatan tertentu untuk tmenggapai tujuan yang diinginkan. Pada aktivitas belajar, motivasi merupakan sebagai segala dorongan di dalam diri siswa yang mengakibatkan, bertanggung jawab, keberlangsungan serta memberi masukan terhadap proses belajar, sehingga tujuan bisa dicapai oleh siswa tersebut. Pada proses pembelajaran, motivasi sangat dibutuhkan, karena individu yang tidak memiliki dorongan pada belajar, maka dapat beraktivitas belajar dalam kesehariannya.

Menurut Munandir dalam (Syaparuddin et al., 2018) mengatakan bahwa belajar merupakan perubahan catatan dalam individu. Perubahan tersebut sebuah kegatan belajar dapat digambarkan pada segala model misalnya perubahan ilmu pengetahuan, pemahaman, tingkah laku, kemampuan, percakapan, habbit atau kebiasaan serta perubahan yang lain pada seseorang.

Demikian juga dikemukakan oleh Abu Ahmadi aktivitas belajar ialah proses perubahan dari masa lalu berupa tingkah laku dan berbagai pengalaman. Menurut Biggs (Motivasi et al., 2020) menyatakan definisi belajar dalam tigas definisi yang berbeda, yaitu, rumusan kuantitatif, rumusan kualitatif dan rumusan institusional. Secara kuantitatif, belajar merupakan aktivitas kognitif berupa fakta tak terhingga.

Kemudian (Sukamto, 2015) menyatakan belajar merupakan bentuk perilaku individual melalui interaksi dengan lingkungan sekitarnya. Menurut Thorndike (Syaparuddin et al., 2018) menyatakan belajar ialah interaksi antara stimulus dan respon. Teori Thorndike, mengubah perilaku belajar bisa tercapai sebagai sebuah perilaku yang terlihat ataupun tidak dapat terlihat.

Dari hasil pemaparan tersebut, pengertian belajar adalah proses memahami, menerapkan, dan menguasai materi yang telah dipelajari selama hidupnya. Sehingga secara garis besar belajar diartikan sebagai pemahaman seluruh tingkah laku individu bersifat tetap merupakan hasil dari pengalaman masa lalu dan aktivitas dengan lingkungan sekitar kemudian melibatkan kognitif. Perubahan tersebut bukan hanya soal ilmu pengetahuan akan tetapi juga berupa ketrampilan, tingkah laku, memahami diri sendiri, dorongan dalam diri serta motivasi.

Kemudian definisi motivasi merupakan kondisi dorongan dari diri individu agar berperilaku dalam menggapai tujuan. Menurut Thomas L. good dan Jere B. Briphy menyatakan motivasi adalah dorongan yang dilakukan pada aktivitas tertentu. Menurut Marx dan Tombouch mencontohkan motivasi sebagai bahan bakar sebuah mesin. Tidak akan bermakna, bagaimanapun hebatnya mesin, jika bahan bakarnya tidak ada sama sekali. Demikian pula dengan belajar, sekolah yang dapat memberikan fasilitas belajar siswa seperti, perpustakaan, laboratorium, internet, semuanya tidak aka nada maknanya jika siswanya tidak mau atau tidak adanya motivasi untuk melakukan aktivitas belajar.

Menurut pendapat Clifford, Mc. Donald (Fadlilah, 2020) menyatakan motivasi memiliki tiga makna yang saling berkesinambungan yaitu proses perubahan energi, munculnya afektif serta reaksi untuk menggapai sebuah tujuan. Jadi dapat disimpulkan bahwa definisi motivasi bisa merupakan: 1) Motivasi dimulai dengan adanya perubahan energi dari dalam diri. Perubahan yang terjadi pada motivasi akibat dari aktivitas neurofisiologis dalam individu, contohnya lapar dikarenakan adanya perubahan dalam sistem pencernaan manusia. 2) Motivasi berasal dari perasaan. Awalnya sebagai ketegangan psikologis, lalu merupakan suasana emosi. Suasana emosi ini menimbulkan perlakuan yang memiliki motif. Misalnya Z terlibat dalam suatu lomba debat, karena $\mathrm{Z}$ tertarik dengan debat tersebut maka dia dengan lancar debat dan akhirnya menang dalam lomba debat tersebut. 3) Motivasi dengan adanya aktivitas dalam menggapai suatu tujuan yang diinginka. Pribadi yang memiliki motivasi melakukan aktivitas yang bertujuan. Aktivitas ini berguna untuk mengurangi rasa cemas yang terjadi akibat perubahan dari diri manusia. Setiap aktivitas adalah cara untuk mencapai tujuan. Contohnya siswa yang ingin memperoleh nilai yang baik, dia harus belajar dengan tekun dan giat.

Teori motivasi dari Santrock (Fadlilah, 2020) menyatakan bahwa aktivitas pemberian dorongan dan tingkah laku. Maksudnya tingkah laku yang tmemiliki motivasi merupakan tingkah laku yang penuh 
kekuatan, arahan dan sersifat dalam jangka waktu yang lama. (Sukamto, 2015) menyatakan bahwa aktivitas motivasi belajar memiliki tigas cara yaitu: 1) suatu aktivitas yang berasal dari dorongan belajar yang mengakibatkan tekanan dari dalam diri. 2) aktivitas belajar yang terarah pada tujuan akan mengurangi tekanan - tekanan tersebut. 3) penggapaian tujuan belajar dan hilangnya tekanan dari siswa. Motivasi memiliki peran penting dalam kegiatan belajar di sekolah, dan belajar mempengaruhi motivasi untuk mencapai tujuan.

Dari hasil pemarapan dari beberapa ahli diatas, disimpulkan motivasi adalah dorongan untuk menjalankan individu untuk berperilaku untuk menggapai tujuannya. Maka motivasi belajar siswa merupakan seluruh dorongan dari siswa yang mengakibatkan aktivitas belajar dan memberikan arahan pada proses pembelajaran, sehingga dapat tercapainya suatu tujuan.

\section{Jenis - Jenis Motivasi}

Motivasi Intrinsik

Motivasi intrinsik adalah suatu kondisi peserta didik yang bisa melakukan aktivitas belajar (Azhar Haq, 2018). Kemudian motivasi intrinsik merupakan keinginan atau dorongan dari dalam diri individu untuk melakukan sesuatu. Bisa juga diartikan bahwa manusia terdorong agar berperilaku untuk menggapai tujuan tanpa adanya faktor lain dari lingkungan sekitar.

Pada proses pembelajaran siswa yang memiliki motivasi secara intrinsic bisa terlihat dari aktivitasnya yaitu rajin pada saat belajar dan menginginkan untuk tercapainya tujuan belajar yang diinginkannya, tidak karena menginginkan pujian, hadiah, dan lain sebagainya.

Sehingga dapat disimpulkan bahwa motivasi diartikan sebagai dorongan atau tekanan dari dalam diri individu untuk menggapai suatu tujuan yang diinginkannya tanpa dorongan dari pihak luar manapun termasuk lingkungan sekitarnya.

\section{Motivasi Ekstrinsik}

Motivasi ektrinsik merupakan faktor dari luar diri individu tersebut. Motivasi ektrinsik dibutuhkan untuk peserta didik ingin untuk belajar. Didalam kelas seluruh siswa yang memiliki dorongan belajar tinggi membutuhkan motivasi ekstrinsik. Para siswa membutuhkan atensi dan pengarahan yang khusus baik dari guru maupun pengajar. Akan tetapi hal tersebut tentunya bukan sebuah prioritas utama bagi seorang siswa atau peserta didik. Para siswa harus bisa memuncukan semangat dorongan belajar untuk menggapai cita citanya kedepannya.

Jadi, dapat disimpulkan bahwa motivasi ekstrinsik adalah motivasi yang muncul akibat adanya dorongan dari pihak luar termasuk lingkugan sekitarnya sehingga individu tersebut ingin untuk melakukan aktivitas atau kegiatan tertentu demi mencapai tujuannya.

\section{Faktor yang Dapat Mempengaruhi Motivasi Belajar}

Berbagai hal yang dapat mempengaruhi adanya motivasi belajar siswa (ARIANTI, 2019) contohnya, pertama cita - cita. Cita-cita merupakan suatu tujuan atau impian yang akan digapai. Penentuan tujuan tersebut berbeda tiap siswa. Kedua kemampuan, kemampuan / skill tersebut merupakan sisi psikologis dadi dalam individu, misalnya kecerdasan, mengamati, perhatian dan daya pikir kritik. Ketiga kondisi, meliputi kondisi psikis (emosi) dan fisik (kesehatan). Kondisi tidak jarang mengganggu kegiatan siswa di sekolah, misalnya saja siswa yang sedang sakit, maka motivasi belajarnya akan menurun pada saat sakit berbeda jika sedang sehat - sehat saja. Kemudian kondisi psikis siswa, misalnya dia sedang mengalami putus cinta, maka akan mengakibatkan dampak negatif bagi siswa yang tidak dapat menstabilkan emosinya dengan stabil. Ia cenderung pendiam daripada mengerjakan tugas sekolahnya. Keempat kondisi lingkungan, hal ini mencakup kondisi lingkungan keluarga, teman sebaya, pergaulan, maupun lingkungan sekolahnya. Kelima yaitu unsur dinamis dalam belajar. Unsur dinamis pada proses belajar merupakan unsur yang pada proses pembelajaran tidak stabil, terkadang menguat, terkadang lemah dan bahkan dapat menghilang khususnya kondisi yang bersifat kondisional misalnya emosi pada siswa, keinginan belajar, kondisi belajar, dan kondisi pada keluarga. Kemudian yang terakhir yaitu cara mengajar guru. Cara mengajar guru tersebut meliputi cara dalam mengajar, berinteraksi dengan siswa, kedisiplinan dan yang lainnya. 


\section{Strategi Meningkatkan Motivasi di Masa Pandemi COVID - 19}

Beberapa indikator perilaku siswa yang mempunyai motivasi yang diarahkan oleh diri Menurut Klausemeler Prayitno, bisa dijelaskan sebagai berikut. Pertama, siswa mengerjakan pekerjaan rumah dengan on time dan berusaha menyelesaikan tugas tersebut dengan baik. Hal ini dikarenakan siswa pada masa pandemi memiliki banyak waktu pada saat dirumah. Hal ini tentunya dapat dimanfaatkan dengan baik dengan mengerjakan tugas tersebut. Kedua, siswa mengerjakan tugas dengan kondisi emosi yang senang. Kondisi emosi tersebut dapat meningkatkan dorongan siswa tersebut dalam mengerjakan tugas - tugasnya. Ketiga, siswa tersebut memiliki tanggung jawab terhadap keberhasilannya dalam belajar. Keempat, siswa menyibukkan diri dengan melakukan hal - hal yang positif dengan perasaan bahagia yang dapat mengembangkan pengetahuan dan ketrampilannya pada masa pandemi. Kemudian yang terakhir yaitu melakukan komunikasi yang baik dengan keluarga agar tetap harmonis dalam menjalin kelekatan dengan keluarga.

Pada penelitian yang dilakukan oleh (Fitri et al., 2016) menyatakan bahwa penyelenggaraan layanan Informasi dengan menggunakan metode blended learning dapat menumbuhkan strategi pembelajaran, keluwesan, dan efektivitas biaya. Selanjutnya blended learning memberikan dukurangn terhadap ketentuan proses pembelajaran dirumah meliputi penurunan biaya, efisien waktu, dan kenyamanan tempat untuk para siswa agar bisa mengerti diri pada sebuah masalah dan bisa memberikan motivasi pada saat proses pembelajaran secara langsung (Fitri et al., 2016). Sanjaya mengatakan bahwa blended learning memiliki nilai sangat tinggi dibandingkan pada proses belajar mengajar seperti biasanya. Dengan adanya pendekatan yang dimafaatkan pada pelaksanaan pelayanan informasi bagi siswa mempunyai dan dapat menumbuhkan motivasi belajar sehingga kesuksesan dalam belajar bisa tercapai. Kemudian menurut penelitian oleh (Jamco, 2015) menyatakan pendekatan digunakan untuk memperoleh keberhasilan untuk memunculkan strategi pembelajaran sehingga tujuan pembelajaran dapat tergapai.

Pada penelitian yang dilakukan oleh (Rosyida et al., 2017) menyatakan bahwa prose belajar menggunakan audio visual lebih efektiv dari pada proses belajar tanpa menggunakan media apapun. Selanjutnya riset yang dilakukan oleh (Pradilasari et al., 2019) menyatakan bahwa menggunakan audio visual bisa lebih mudah membantu memahami materi, kemudian riset oleh (Pradilasari et al., 2019) menyatakan pembelajaran siswa dengan menggunakan audio visual memiliki keinginan untuk belajar yang lebih tinggi. Berdasarkan penelitian oleh (Pradilasari et al., 2019) menyatakan bahwa media berbasis audio visual bisa menumbuhkan motivasi belajar pada siswa. Media audio visual adalah metode pembelajaran yang menyajikan gambar dan suara dalam satu tampilan dengan menggunakan aplikasi tertentu (Pradilasari et al., 2019).

Pada penelitian yang dilakukan oleh (Hidayati, 2014) menyatakan bahwa pembelajaran dnegan menggunakan media komik dapat meningkatkan motivasi belajar Bahasa Indonesia dan ketrampilan membaca siswa kelas IV SDN Padokan 2 Bantul. Media pembelajaran dengan menggunakan komik dapat meningkatkan motivasi belajar Bahasa Indonesia dan sesuai dengan (Budiarti \& Haryanto, 2016) media komik terbukti efektif untuk meningkatkan motivasi belajar para siswa terutama pada hal membaca. Berdasarkan penelitian oleh (Safitri, Firharianti \& Sahal, 2017), menyatakan bahwa penerapan Strategi Rolled dapat menumbuhkan kwalitas pembelajaran, dikarenakan pada pembealajaran ini diharuskan peran aktif siswa secara intelektual dan emosi. Strategi pembelajaran dengan Rolled adalah strategi pembelajaran dalam bentuk game yang bisa meningkatkan motivasi belajar siswa dalam proses pembelajaran didalam kelas. Metode pembelajaran ini menggunakan alat berbentuk lingkaran yang dibagi menjadi mcam - macam wilayah. Wilayah - wilayah tersebut berisi angka yang harus dijawab oleh siswa.

Pada beberapa penelitian terdahulu ada beberapa upaya dan strategi untuk meningkatkan motivasi belajar pada siswa. Misalnya pada penelitian oleh (Musyarrof et al., 2018) yang membuktikan bahwa upaya untuk menumbuhkan motivasi belajar siswa melalui peran aktif guru dengan semakin terlihat apabila dikaitkan dengan peningkatan mutu lulusan atau hasil dari pendidikan itu sendiri. Kemudian pada penelitian yang dilakukan oleh (Cumayunaro, 2019) menunjukkan bahwa agar memperoleh hasil belajar maksimal maka, seorang guru harus kreatif menumbuhkan motivasi belajar siswa dikarenakan apabila guru kreatif, maka siswa lebih tergugah untuk belajar. Pada penelitian selanjutnya strategi pembelajaran inquiri efektif diterapkan peda mata pelajaran PPKN khususnya di kelas VIII. Penggunaan strategi pembelajaran inquiri pada proses pembelajaran terbukti dapat meningkatkan motivasi belajar siswa dan membawa dampak positif bagi kognitifnya. 
Setelah itu pada riset yang dicoba oleh (Oktivianto et al., 2018) yang menampilkan kalau tata cara Role Play bisa digunakan seorang guru buat menimbulkan motivasi belajar pada siswa, yaitu dengan cara ikatan yang interaktif antara guru dengan para siswa ataupun antar siswa dengan dialog serta peragaan, sehingga siswa bisa meningkatkan perasaan, nilai, perilaku, serta bermacam strategi dalam membongkar perkaranya.

Berikutnya, (Rahardja et al., 2018) pada hasil penelitiannya dicoba pada suatu halaman Anak- anak di Tanggulangin mengatakan kalau buat tingkatkan motivasi belajar siswa bisa memakai tata cara Whole Barin Teaching ialah mewajibkan guru buat berupaya menarik atensi siswa supaya lebih fokus terhadap modul pendidikan yang di informasikan oleh guru. Setelah itu pada riset yang dilakukan oleh (Febnasari et al., 2019) menyatakan bahwa Metode Diskusi Kelas dengan Strategi "TPS" efektiv dan bisa digunakan sebagai variasi pembelajaran yang dapat membuat siswa tidak jenuh dan merasa bahagia mengikuti pembejaran tematik. Strategi pembelajaran TPS adalah salah satu strategi pembelajaran yang kooperatif yang mengaharuskan adanya proses berpikir, berkelompok dan berbagi. Pada penelitian sebelumnya strategi pembelajaran TPS dapat meningkatkan motivasi belajar siswa dan kerja sama dalam kelompok (Febnasari et al., 2019).

Pada penelitian yang dilakukan oleh (Adi \& Iqbal, 1999) menyatakan bahwa tingginya motivasi belajar siswa juga dapat disebabkan oleh virtual laboratory dapat menarik minat siswa (Adi \& Iqbal, 1999), memudahkan siswa dalam hal menyediakan alat dan bahan memberikan kebebasan siswa dalam proses praktikum secara daring memberikan kebahagiaan kepada para siswa dikarenakan mereka dapat mengulangi lagi proses percobaan praktikum tersebut (Adi \& Iqbal, 1999). Virtual laboratory merupakan media yang interaktif yang dapat menggugah aktivitas dilaboratorium seolah - olah siswa berada di laborarotium asli (Adi \& Iqbal, 1999), kemudian Virtual Laboratory juga dapat mengatasi berbagai permasalahan dalam proses pembelajaran seluruh siswa. Kemudian adapun strategi yang dapat membantu siswa untuk menumbuhkan motivasi belajar. Menurut (Aritonang et al., n.d.) strategi ini bernama Spotlight adalah lampu sorot dimana seorang siswa secara acak maju didepan kelas. Siswa duduk di kursi, atau memakai syal yang menandakan "mantel sang ahli". Seorang siswa secara sukarelawan maju ke depan kelas untuk menjawab pertanyaan yang ditanyakan oleh guru berdasarkan materi yang sudah dipelajari. Strategi tersebut terbukti dapat menumbuhkan motivasi belajar siswa di Pekanbaru Riau 2019.

Pada riset yang dilakukan oleh (Wuryanti \& Kartowagiran, 2016) menyatakan bahwa proses pembelajaran yang menarik dan melibatkan siswa secara langsung yang mendasari adanya video animasi tersebut. Video animasi terdapat berbagai tiruan fantasi sehingga menjadikan siswa lebih tertarik. (Wuryanti \& Kartowagiran, 2016) menyatakan, "Animations might be more attractive and motivating". Teori pemodelan ini didukung oleh teori pengkodean ganda yang ditemukan oleh Paivio ialah melaporkan kalau data yang diterima oleh siswa dalam wujud visual serta digabungkan dengan data dalam wujud visual yang dikemas dalam media pendidikan bisa mendukung memori serta uraian siswa terhadap modul sehingga pendidikan jadi lebih efisien. Pada penelitian lain yang dilakukan oleh (Suwondo et al., 2019) menyatakan bahwa Genius learning atau holistic learning merupakan pendekatan praktis yang digunakan guru dalam proses pembelajaran siswa untuk meningkatkan motivasi belajar siswa. Dalam hal ini terbukti adanya peningkatan dalam motivasi belajar siswa tersebut.

Penelitian oleh (Musyarrof et al., 2018) mengatakan bahwa strategi yang bisa dilakukan untuk meningkatkan motivasi belajar para siswa yaitu salah satunya dengan strategi pembelajaran yang bernama ARCS. Srategi pembelajaran ini dikembangkan oleh John M. Keller. Berdasarkan atas empat struktur yaitu perhatian, relevansi, kepercayaan diri, dan kepuasan. Kemudian dengan komunikasi persuasif, guru dapat mengajak siswanya untuk berinteraksi dengan baik tanpa adanya pemaksaan dari manapun. Kemudian motivasi belajar bisa tumbah dari dalam diri individu. Sifat komunikasi persuasif yang menipu bisa meyakinkan siswa, bahwa dalam pembelajaran sebuah materi yang disampaikan sangat penting untuk dipahami. Sehingga siswa dengan sendirinya dapat termotivasi untuk mempelajari materi yang diajarkan oleh guru. SAVI yaitu artinya Somatic (bersifat raga), Auditori (bersifat suara), Visual (bersifat gambar), dan Intelektual (bersifat merenungkan). Kemudian berdasarkan Teori Melvin L. Siberman strategi bernama hembusan angin kencang merupakan kegiatan yang memberikan siswa kebebasan untuk bergerak serta tertawa, dan bisa membongkar kebekuan yang terjalin pada siswa sepanjang proses pendidikan. Hal tersebut dibuktikan dengan riset yang dilakukan oleh (Anggraini, 2019) yang menyatakan bahwa strategi pembelajaran yang bernama hembusan angina kencang bisa meningkatkan motivasi belajar siswa pada mata pelajaran Bahasa Indonesia di kelas V Sekolah Dasar Negeri 20 Pekanbaru. 
Strategi quantum learning, merupakan cahaya yang diubah menjadi sebuah energi dalam bentuk interaksi. Jadi quantum learning adalah seni mengolah karya musik yang dikemas dalam interaksi pada momen pembelajaran. Segala unsur keberhasilan belajar harus diramu menjadi sesuatu persembahan yang akan memunculkan kondisi belajar yang nyaman (Sukamto, 2015). Aktivitas pembelajaran menggunakan strategi tersebut bisa lebih mencuri atensi \& membahagiakan dan dapat menggunakan seluruh potensi yang ada pada proses belajar, sehingga siswa merasa nyaman, memiliki dorongan dan memiliki kemauan yang tinggi dalam proses belajar. Kemudian penelitian oleh (Adi \& Iqbal, 1999) menyatakan strategi pendidikan lightening the learning climate dapat berguna untuk mengaitkan para siswa pada pendidikan ialah untuk membuat sebuah lelucon - lelucon yang kreatif yang berhubungan dengan modul pembelajaran, serta pada saat waktu yang bersamaan bisa mengajak para siswa agar berpikir sehingga terbukti dapat meningkatkan motivasi belajar siswa.

Dapat disimpulkan bahwa strategi untuk meningkatkan motivasi belajar siswa pada saat pandemi virus covid - 19 sangatlah beragam yaitu dengan cara komunikasi persuasif, Teknik ARCS, menggunakan media video animasi, Virtual Laboratory, peran guru yang aktif, guru yang kreatif, Diskusi Kelas, Metode Role Play, Media Komik, Media Audio Visual, Metode Blended Learning, Strategi quantum learning, strategi pembelajaran lightening the learning climate, kemudian strategi pembelajaran Think Pair Share (TPS), Genius learning, Strategi Pembelajaran SAVI, strategi hembusan angin kencang, strategi pembelajaran inquiri, Model Pembelajaran Kooperatif Strategi Spotlight.

\section{Hambatan dalam Meningkatkan Motivasi Belajar di Masa Pandemi COVID - 19}

Aspek penghambat yang berkaitan dengan orang tua siswa. Orangtua adalah salah satu aspek dari lingkungan sekitar bisa pengaruhi perhatian belajar, dorongan dari orangtua dapat berbentuk dorongan emosi yaitu keperdulian, atensi, dan motivasi, dorongan penghargaan (dorongan bersifat positif ataupun pemberian penghargaan), dorongan instrumental (bayaran serta sarana belajar), dan dukungan data (arahan, anjuran, nasihat) (Safitri, Firharianti \& Sahal, 2017). Tidak hanya tersebut, atensi yang diberikan orang tua terhadap anak bisa menumbuhkan motivasi belajar individu pada saat mengerjakan tugas sekolahnya (Jamco, 2015). Terlebih apabila pada peraturan ini pendidikan di sekolah ditukar dengan adanya pemberian tugas dirumah. Orangtua saat pandemi virus covid - 19 mempunyai hubungan yang signifikan terhadap individu pada saat melaksanakan proses pembelajaran siswa, entah secara struktur, pembagian tugas sebagian peraturan (Fadlilah, 2020). Berdasarkan uraian tersebut membuktikan bagimana pentingnya kedudukan orangtua dalam penerapan sekolah dirumah pada saat terdapatnya virus covid-19 yang mengharuskan setiap individu untuk melaksanakan seluruh kegiatan di rumah, keharusan belajar untuk siswa yang sedang melakukan proses pembelajaran.

Aspek selanjutnya yang bisa membatasi usaha guru untuk meningkatkan motivasi belajar siswa berhubungan dengan adanya sarana dan prasarana pendidikan. Pada penerapan pembelajaran dari rumah ini pasti fasilitas yang sangat diperlukan merupakan adanya handphone untuk sebagai alat dalam proses pembelajaran jauh antara guru dengan seluruh siswa. Fasilitas serta prasarana pendidikan mempunyai hubungan yang signifikan dalam menumbuhkan motivasi belajar siswa, apabila fasilitas sarana bertambah, sehingga sebaiknya diimbangi pula dengan meningkatnya motivasi belajar siswa (Arianti, 2019).

\section{Simpulan}

Kesimpulan dari riset diatas menyatakan bahwa strategi untuk meningkatkan motivasi belajar siswa pada saat pandemic covid - 19 sekarang ini berbagai macam seperti, komunikasi persuasif, Teknik ARCS, menggunakan media video animasi, Virtual Laboratory, peran guru yang aktif, guru yang kreatif, Diskusi Kelas, Metode Role Play, Media Komik, Media Audio Visual, Metode Blended Learning, Strategi quantum learning, strategi pembelajaran lighteing the learning climate, kemudian strategi Pembelajaran Think Pair Share (TPS), Genius learning, Strategi Pembelajaran SAVI, strategi hembusan angin kencang, strategi pembelajaran inquiri, Model Pembelajaran Kooperatif strategi spotlight, melibatkan guru untuk membantu siswa, mengadakan kompetisi, memberikan pujian, memberikan nilai, dan memberikan penghargaan terhadap siswa. Pemahaman dari siswa seoptimal apapun cara untuk meningkatkan motivasi akan tetapi jika tidak ada keinginan dari dalam diri sendiri maka motivasi tersebut tidak akan pernah dapat tercapai. 


\section{Ucapan Terimakasih}

Ucapan terimakasih diberikan kepada seluruh pihak yang telah berkontribusi dalam penulisan artikel ini, sehingga penulisan artikel dapat tersusun hingga selesai

\section{Refrensi}

Adi, W. C., \& Iqbal, M. (1999). Virtual laboratory. Choice Reviews Online, 36(11), 36-6309-36-6309. https://doi.org/10.5860/choice.36-6309

Anggraini, W. (2019). Penerapan strategi hembusan angin kencang untuk meningkatkan motivasi belajar siswa pada mata pelajaran bahasa indonesia di kelas v sekolah dasar negeri 20 pekanbaru. PENTAS: Jurnal Ilmiah Pendidikan Bahasa Dan Sastra Indonesia, 5(1), 81-88.

ARIANTI, A. (2019). Peranan Guru Dalam Meningkatkan Motivasi Belajar Siswa. DIDAKTIKA : Jurnal Kependidikan, 12(2), 117-134. https://doi.org/10.30863/didaktika.v12i2.181

Aritonang, N. A., Irianti, M., Education, P., \& Program, S. (n.d.). APPLICATION OF COOPERATIVE LEARNING MODEL OF SPOTLIGHT STRATEGY TO IMPROVE LEARNING MOTIVATION OF SMP N 8 PEKANBARU STUDENTS STRATEGI SPOTLIGHT UNTUK MENINGKATKAN MOTIVASI. 1-10.

Azhar Haq. (2018). Motivasi Belajar Dalam Meraih Prestasi. Vicratina, 3, 193-214.

Budiarti, W. N., \& Haryanto, H. (2016). Pengembangan Media Komik Untuk Meningkatkan Motivasi Belajar Dan Keterampilan Membaca Pemahaman Siswa Kelas Iv. Jurnal Prima Edukasia, 4(2), 233. https://doi.org/10.21831/jpe.v4i2.6295

Cumayunaro, A. (2019). MENARA Ilmu Vol. XIII No.5 April 2019. Jurnal Penelitian Dan Kajian Ilmu, XIII(5), 124. https://jurnal.umsb.ac.id/index.php/menarailmu/article/view/1397

Fadlilah, A. N. (2020). Strategi Menghidupkan Motivasi Belajar Anak Usia Dini Selama Pandemi COVID19 melalui Publikasi. Jurnal Obsesi: Jurnal Pendidikan Anak Usia Dini, 5(1), 373. https://doi.org/10.31004/obsesi.v5i1.548

Febnasari, S. D., Arifin, Z., \& Setianingsih, E. S. (2019). Efektifitas Penggunaan Metode Pembelajaran Diskusi Kelas dengan Strategi "TPS" untuk Meningkatkan Motivasi Belajar. Jurnal Ilmiah Sekolah Dasar, 3(3), 315. https://doi.org/10.23887/jisd.v3i3.19456

Fitri, E., Ifdil, I., \& S., N. (2016). Efektivitas layanan informasi dengan menggunakan metode blended learning untuk meningkatkan motivasi belajar. Jurnal Psikologi Pendidikan Dan Konseling: Jurnal Kajian Psikologi Pendidikan Dan Bimbingan Konseling, 2(2), 84. https://doi.org/10.26858/jpkk.v2i2.2250

Hidayati, Y. M. (2014). Penerapan Strategi Cooperative Script Dengan Media Komik Untuk Meningkatkan Motivasi Belajar Siswa Kelas V Pada Mata Pelajaran Bahasa Indonesia. Jurnal Profesi Pendidikan Dasar, 1(1), 42-43.

Jamco, m. taher. (2015). Jurnal Biology Science \& Education 2015 ANGGI TIAS. P. Gottfredson, 4(1), $74-$ 82. http://dx.doi.org/10.33477/bs.v4i1.531

Motivasi, P., Santri, B., Pondok, D., Miftahul, P., Menurut, T., \& Uno, H. B. (2020). eL_Huda, Volume 11, Nomer 2/2020 16. Journal of Healthcare Technology and Medicine, II, 5-6.

Musyarrof, A. F., Nugroho, S. E., \& Masturi, M. (2018). The Analysis of Students' Critical Thinking Weakness in Senior High School on Physics Learning. 3, 17-32. https://doi.org/10.2991/iset18.2018 .8

Oktivianto, O. I., Hudaidah, H., \& Alian, A. (2018). Pengaruh Implementasi Model Pembelajaran Role Playing dengan Media Film terhadap Motivasi Belajar Peserta Didik dalam Pelajaran Sejarah Materi Perang Palembang Kelas X di SMA Srijaya Negara Palembang. Jurnal Pendidikan (Teori Dan Praktik), 3(2), 113. https://doi.org/10.26740/jp.v3n2.p113-118

Pradilasari, L., Gani, A., \& Khaldun, I. (2019). Pengembangan Media Pembelajaran Berbasis Audio Visual pada Materi Koloid Untuk Meningkatkan Motivasi dan Hasil Belajar Siswa SMA. Jurnal Pendidikan Sains Indonesia, 7(1), 9-15. https://doi.org/10.24815/jpsi.v7i1.13293

Prasojo, R. J. (2016). Pengaruh perhatian orang tua dan kedisiplinan siswa terhadap prestasi belajar mata pelajaran IPS. Jurnal Penelitian Dan Pendidikan IPS, 9(2), 1131-1149. https://media.neliti.com/media/publications/37082-ID-pengaruh-perhatian-orang-tua-dankedisiplinan-belajar-terhadap-prestasi-belajar.pdf 
Rahardja, U., Aini, Q., Ariessanti, H. D., \& Khoirunisa, A. (2018). Pengaruh Gamifikasi pada iDu (iLearning Education) dalam Meningkatkan Motivasi Belajar Mahasiswa. NJCA (Nusantara Journal of Computers and Its Applications), 3(2), 120-124. https://doi.org/10.36564/njca.v3i2.85

Rosyida, S., Munzil , M., \& Joharmawan, R. (2017). Pengaruh Penggunaan Media Audio Visual Dalam Pembelajaran Problem Posing Terhadap Motivasi Dan Hasil Belajar Larutan Penyangga. J-PEK (Jurnal Pembelajaran Kimia), 2(1), 41-52. https://doi.org/10.17977/um026v2i12017p041

Safitri, Firharianti, \& Sahal, M. (2017). The Implementation of Learning Strategy Aactive Rolled to Improve the Students' Motivation of the Second Years Science Physics at SMPN 40 PEKANBARU. 44, 112 .

Sukamto, S. (2015). Pembelajaran Matematika Strategi Quantum Learning Untuk Meningkatkan Motivasi Belajar Siswa. Malih Peddas (Majalah Ilmiah Pendidikan Dasar), 4(2), 21-25. https://doi.org/10.26877/malihpeddas.v4i2.535

Suwondo, H., Ruslan, D., \& Yus, A. (2019). Penggunaan Strategi Genius Learning Untuk Meningkatkan Motivasi Dan Hasil Belajar Ips Siswa Pada Kelas V SDN 028229. Jurnal Tematik, 9(1), 54-61.

Syaparuddin, Meldianus, \& Elhami. (2018). Strategi Pembelajaran Aktif Dalam Meningkatkan Motivasi Belajar PKn Peserta Didik. Jurnal Pendidikan Guru Sekolah Dasar, 2(1), 31-42.

Uno, H. B., \& Ma'ruf, A. R. K. (2016). Pengembangan Media Pembelajaran IPS Berbasis Website untuk Siswa Kelas VII Madrasah Tsanawiyah Negeri. JTP - Jurnal Teknologi Pendidikan, 18(3), 169-185. https://doi.org/10.21009/jtp1803.1

Wuryanti, U., \& Kartowagiran, B. (2016). Pengembangan Media Video Animasi Untuk Meningkatkan Motivasi Belajar Dan Karakter Kerja Keras Siswa Sekolah Dasar. Jurnal Pendidikan Karakter, 6(2), 232-245. https://doi.org/10.21831/jpk.v6i2.12055

Article Information (Supplementary)

Conflict of Interest Disclosures:

The authors declare that they have no significant competing financial, professional or personal interests that might have influenced the performance or presentation of the work described in this manuscript.

Copyrights Holder: < Eis Imroatul Muawanah ><2021>

First Publication Right: JIBK Undiksha

https://doi.org/10.xxxx/ $\mathbf{x x x x x}$

Open Access Article | CC-BY Creative Commons Attribution 4.0 International License.

Word Count: 